\title{
LITERARY TEXT AS A SOURCE FOR UNDERSTANDING CONFLICTS IN CONTEMPORARY REALITY (POLITICAL VIOLENCE AND TERRORISM)
}

\author{
Tatiana Voronchenko ${ }^{1}$, Olesya Kovrizhnykh ${ }^{2}$, Ekaterina Fyodorova ${ }^{3}$
}

\begin{abstract}
Political violence in the modern world is developing in many ways and in forms that are more radical than ever before. In the second half of the last century, and the start of this current one, the ethno-social conflicts (terrorism being the most extreme) have been one of the most pressing global issues of our time.

Various aspects of ethno-social conflict, with terrorism as an extreme form of political violence, are now the subject of artistic interpretation for contemporary authors. The study of literary text for understanding conflicts in the contemporary reality is significant, since writers consider certain factual material in their works. These writers strive to emphasize and describe personal and social layers of ethno-social conflicts, to reveal their peculiarities and consequences.

This study compiles a theoretical framework for the study of literary text as a source for understanding the conflicts of contemporary reality. It uses a complex approach that provides a profound analysis of causes and effects, and the nature and content of political and ethno-social conflicts, including the principles of political studies and comparative literature.

The authors of this present study conclude that the great concern of the world's writers about ethno-social issues and conflicts is the inter-ethnic and inter-cultural contradictions that closely connect to the crisis of multiculturalism in the USA and Western Europe. Contemporary writers focus on themes, like the islamization of Europe, inter-confessional conflicts, total changes in inter-ethnic relations, fragmentation of the single universal cultural space, and social and cultural transformation leading to conflicts. Examples include Andrei Volos' Maskavskaya Mecca, and Elena Chudinova's The Mosque of Notre Dame. Some authors ponder over the terrorism as an extremist reaction to social injustice or inner personal, cultural, and religious contradictions, as seen in John Updike's Terrorist and Don DeLillo's Falling Man.
\end{abstract}

UDC Classification: 327, DOI: http://dx.doi.org/10.12955/cbup.v3.622

Keywords: terrorism, political violence, literary representation of conflict

\section{Introduction}

Political violence in the modern world is developing in many ways and in forms that are more radical than ever before. In the second half of the last century and the start of this present one, ethno-social conflicts, with terrorism the most extreme, have been one of the most pressing global issues of our time.

Various aspects of ethno-social conflict, including terrorism as an extreme form of political violence, are now the subject of artistic interpretation by contemporary authors. The study of literary text as a source for understanding conflicts in contemporary reality is significant, since writers consider certain factual material in their works. Writers strive to emphasize and describe personal and social layers of ethno-social conflicts, to reveal their peculiarities and consequences.

\section{Literature review}

The great concern of the world's writers about ethnic-social issues and conflicts is the inter-ethnic and inter-cultural contradictions that closely connect to the crisis of multiculturalism in the USA and Western Europe. Contemporary writers focus on themes, like islamization of Europe, interconfessional conflicts, total changes in inter-ethnic relations, fragmentation of single universal cultural space, and social and cultural transformation leading to conflicts. Examples include the works of Andrei Volos (2003) and Elena Chudinova (2005). Some authors ponder over terrorism as an

\footnotetext{
${ }^{1}$ Tatiana Voronchenko, Professor, Literature and Journalism Department, Transbaikal State University, Russian Federation, tavoronch@mail.ru

${ }^{2}$ Olesya Kovrizhnykh, Assistant Professor, Political Studies Department, Transbaikal State University, Russian Federation, olesya.kovrizhnyx@mail.ru

3 Ekaterina Fyodorova, Postgraduate, Literature and Journalism Department, Transbaikal State University, Russian Federation, katyaz@bk.ru
} 
extremist reaction to social injustice or inner personal cultural and religious contradictions, for example the works of Terrorist (Updike, 2006), and Falling Man (DeLillo, 2007).

This study compiles the theoretical framework for the study of a literary text as a source for understanding conflicts of contemporary political reality using the complex approach providing the profound analysis of causes and effects, and the nature and content of political and ethno-social conflicts, including the principles of political, sociological, cultural and literary studies. Researchers such as Antonius (2013), Antonyan (1998), Belkov (2002), Bjørgo (2004), Dashkova \& Karchagin (2013), Levashov (2007), Maltseva (2007), Manyukov (2010), Moghaddam (2006),) and others study the phenomenon of terrorism from different perspectives. While studying the reflection of contemporary political reality in fiction of recent years we use comparative-historical and literaryhistorical methods to identify topics and problems in literary texts.

Contemporary political science treats terrorism as violence that is politically motivated. A Russian lawyer and researcher of terrorism, examined terrorism from the perspective of criminology and the criminal legal framework: "Terrorism is frightening; it acts as a means of weakening the enemy through physical and mental effects on the opposing side" (Antonyan, 1998, p. 8). He stressed that terrorism is violence that contains a threat to instill fear and panic, and to destroy political and social order. Antonyan (1998) highlights the main features of terrorism that distinguish it from other types of violence. It is mainly frightening and a demonstration of force; and as a whole, is the very meaning of a terrorist act (Antonyan, 1998). This point of view coincides with the definition of terrorism by Bruce Hoffman, "any especially abhorrent act of violence perceived as directed against society" (Hoffman, 2013 , p. 1). Belkov (2002) considers terrorism in the political sphere "the strategy and tactics of certain forces, oriented to the violent methods of suppression of their opponents" (Belkov, 2002, p. 17). As a social phenomenon, terrorism in practice is the ideology and policy of social forces that focus on violent forms of illegal reforms in the state and social system. A researcher of intercultural communication from the United Kingdom, Mona Baker, notes that, not in the least, is this role played by the so-called "narratives" of terrorism, when she writes, "Public narratives of terrorism and security now pervade our lives and are elaborated by a range of influential institutions, including some that present themselves as non-partisan and apolitical" (Baker, 2010, p. 362). In many cases, international terrorist organizations operate more efficiently than those government agencies and special services designed to resist them.

Contemporary American writer Don DeLillo (2007) models the psychology of a terrorist (the image of Hammad) in his novel Falling man. The novel is a response to the events of September 11, 2001 in New York and focuses on the problems of terrorism, namely destruction, and suffering that terror brings to people. Hammad, one of the members of the 9/11 terrorist group, is "zombied" by the jihad ideology, he is ready to take revenge for the fact that American forces are "defiling the Land of the Two Holy Places" (Saudi Arabia) (p. 175). Hammad believes that a martyr's death will open his way to heaven. However, for some time he is concerned about whether he has the right to take the life of others. DeLillo wrote that Mentor Amir inspires the jihadists, by "What about the others? Amir said simply there are no others. The others exist only to the degree that they fulfill the role we have designed for them" (DeLillo, 2007, p. 176). The justification of murder in the name of God reveals the danger of religious fanaticism that guides by myths instead of reality, and denies the value of life. DeLillo's novel presents the evolution of a particular person, which begins as apolitical and ends with self-sacrifice by engaging in a heinous terrorist attack.

Another classic of contemporary American literature is John Updike's novel Terrorist (2006). It attempts to analyze how a terrorist's psychology forms. The protagonist of the novel, Ahmad, together with his study of Arabic and the Koran reading, revolves around the activities of Islamic terrorist organization. It is interesting that Ahmad grew up in America; he has never been abroad and was far 
from Islamic culture. Russian scholars, Voronchenko, Vinogradova, and Zherebtsova (2014) assume that terrorist organizations use rather weak mentality of a teenager for destructive purposes, in noting, "Faith, a gradual and orderly learning of the classical Arabic language, thinking about the greatness of God - that's what Ahmad is seeking: the core traits of his personality in the beginning of the story. Disharmonious relations with other people only aggravated his desire to go into his inner world" (p. 237).

Structuring terrorist activities could help to realize the goals of the terrorists. Based on purpose, terrorism comprises three types:

1) social (or internal). Its goal is a partial change in the economic or political system of the country;

2) nationalistic. It is practiced by separatist organizations that set out to fight against the dictates of hostile states and monopolies; and

3) religious. It is associated with the fight of adherents of one religion (or cult) in the framework of a common state with the adherents of other or with an attempt to overthrow the secular government and to affirm religious authorities.

There are several main causes of terrorism, according to the Institute of Social and Political Studies of Russian Academy of Science survey (Levashov, 2005). These include the division of the world because of the energy and minerals' markets; war between Christian and Muslim civilizations; intensification of contradictions between the rich north and the poor south; division of the world into a unipolar model with the center as the United States; robbery; and the inability of politicians to meet challenges of human development. In this regard, a terrorism researcher, Manyukov (2010), offers an interesting point of view when he writes, "The war against the mind and soul" he points out that the main causes of terrorism are "manifestations of neo-colonialism as a system of political, national, social, and economic oppression" (p. 39). This cause, as Manyukov remarks, results through inciting ethnic and religious hatred.

Another factor for conflicts of contemporary political reality is crisis (economic, political, cultural, and religious) in a particular state. Religious and ethnic terrorism are closely intertwined. In the 19th century, the goals of terrorists were to achieve national liberation or a world social revolution, with the help of terrorist acts directed against certain important government entities (the murder of emperors, kings, and officials). For example, in the last half of the 19th century, in Russian radical literature and social thought, the notion of nihilism and terror or terrorism equated with one another. Voronchenko and Zherebtsova (2013) wrote: "at this time individual terror was considered in Russia as the main tool of revolutionary struggle" (p. 52). Russian writers of that period belonged to the revolutionary democratic Narodniki movement, which formed a significant and very special literary trend of the 1870s. A writer, Sergey Stepnyak-Kravchinsky, a former member of the terroristic organization, People's Will, argued that the use of terror was a natural response to the existence of a despotic rule. His novel The Career of a Nihilist (1889) is about a terrorist named Andrey Kozhukhov, who tries, but fails, to assassinate the tsar. The end of the 20th century gives a new wave of terrorism development, the main purpose of which is to maximize the number of victims, in order to frighten and intimidate potential enemies and real opponents. The end of 20 th - beginning of 21 st century is a time of a new surge of terrorism in the form of Islamic extremism.

A new book of the popular French writer Michel Houellebecq, Submission, published January 7, 2015, became a fatal warning. The novel tells the story of 2022, when the French presidency is won by a Muslim, and is characterized by anti-Islamic attitude. On the day it was published, Islamic terrorists organized an attack on the editorial office of the French satirical weekly, Charlie Hebdo, in Paris, and 
killed 12 people. It is well known that 10-12 years ago Russian writers had already written about the possible dominance of Islamic culture in Europe. These were the novels of dystopias by Andrei Volos (2003) with Maskavskaya Mecca, and Elena Chudinova (2005) with The Mosque of Notre Dame. These novels present a futurological concept, realized in the framework of the post-Soviet arthistorical discourse. The genre of dystopia is one of the most dynamic in contemporary Russian literature. The Russian scholar Chantsev (2007) suggests it is because of the Russian socio-political changes in the late 20th century, and reports that:

anti-utopian themes in the literature are common in an era when society proves that the current situation is has been working for a long time and has a tendency to become worse in the future, and people have a feeling of alienation from active participation in the historical process (p. 270)

Such writers as Andrei Volos and Elena Chudinova represent artistic expression of what current condition of the post-industrial society can cause.

The novel Maskavskaya Mecca by Andrei Volos portrays Moscow, which has become a new Mecca, the city (with a predominantly Muslim population), entitled "Maskawa", in Turkic style. The only salvation for non-Muslims is the "emigration" in to the fictional communist village. The novel describes riots and people's discontent:

Why do we have experienced the horrors of the Great Confluence? To die of hunger? What for our fathers were killed? - so that the children will never have a job? They say that now all are equal! The world is happy! There are no Christians or Muslims or Buddhists! We are all brothers in one God! But take a look around! We are rotting in poverty! They are bathing in luxury! Is it equality?! (Volos, 2003, p. 9).

We agree with the point of view of the literary scholar Lobin (2014), who said, "The driving force of described social explosion is social inequality and a sense of uselessness". The problems presented in the Volos's novel are largely psychological, social, and cultural processes, which are caused by the basic collective destructive emotions. It becomes clear that the reasons for the bloody events of the novel were not only ethnic, but also social conflict. A much more acute class inequality problem supplemented the motive for ethnic strife in the novel.

The dystopian novel The Mosque of Notre Dame by Elena Chudinova is set in Paris in 2048, when the European Union is known as Euro-Islam. Most Europeans are Islamic and live under Shariah law. Notre Dame, after a small architectural restructuring, becomes a mosque. The other national minorities live in the ghetto. However, there is underground resistance movement. The Christian community illegally holds services. Rebels learn about preparing operations to destroy the ghetto and combine to capture Notre Dame. Their goal is to make Notre Dame a Christian church again, just for one day, and to bless it, serve a mass and then explode it. The novel ends with the destruction of the cathedral.

Literary researchers give different assessments of Elena Chudinova's novel. Some consider it as a mass literature product (Lanin, 2008; Bondar-Tereschenko, 2014). Others see it as a warning with a set of xenophobic and nationalistic superstitions, stereotypes, and apprehensions (Malashenko, 2006; Romanova, 2013). According to these researchers, Chudinova appeals to readers directly, expressing her concern with today's problems. The blurring of fiction and nonfiction expresses this idea, which appears a characteristic feature of contemporary literature.

Together with the writers, social psychologists analyze the reasons why people enter terrorist organizations (mostly Islamized). It is most likely that people who have experienced the negative impact of personal and community deprivation become candidates to take part in mass antigovernment activities or terrorist acts. An American-Iranian social psychologist, Mohaddam (2006), suggests this idea when he writes: 
From the terrorists' point of view: What they experience and why they come to destroy"; "among Muslim communities in Western Europe and North America the young in Islamic communities have experienced a deep identity crisis" and "Revolutions, war, mass migration of populations, vast economic and social transformation - these form the backdrop to the identity crisis of the young in the Islamic world" (p. 37).

The leaders of terrorist organizations and sects often recruit common people from the Islamic world (even the women and adolescents) who are willing to die for the sake of their common goal. They experience community deprivation, pessimism associated with the disadvantaged position of the group in society. For example, a Muslim who migrated to another (for example, Catholic) country may be experiencing deprivation because of the comprising position of Muslims compared with other religious or social groups in the country. The motives of wanting to join a terrorist group are many. They include serving for a greater ideology, a result of poverty, misery, and fanaticism caused by social pessimism, the despair and a feeling of not being able to change lives for the better, or feelings of aggression and revenge that are based on infringement of national and religious rights or as an inadequate response to increasing globalization. Researchers Dashkova and Karchagin (2013) confirm, "a base of every terrorist act is the protest against that how specific national, economic, and other rights are provided for a particular group of people" (p. 77). Unfair social reality, where the person does not feel protected, cannot relieve the loss of national values, loneliness causing aggression, and readiness to resist the government. All over the world, there are people who think that a better fate for them is to join a terrorist organization to express their revenge.

Researchers in the field of political science, sociology, cultural studies, psychology, literature, and writers from different countries, are trying to figure out whether one can bring people back from the terrorist organizations to peaceful living conditions. Maltseva (2007) states in her article "Terrorism in alternative conditions of 'American' globalization" that balanced economic and political strategy will weaken social conflicts in the world, as well as root out political and cultural factors conducive to terrorism. The Lithuanian scholar, Žindžiuvienè (2013), highlights the danger in forming destructive moral attitudes directed against the so-called "image of the enemy":

The world entered the era of moral and/or physical executions: designs for punishing the evil forces have been continuously elaborated, elements of binary opposition and segregation appeared in many societies, and instead of making attempts to understand, discuss or explain, the extremism of Islamic fundamentalists was echoed in the form of the so-called "western extremism" - demonizing Islam and Muslim traditions (p. 74).

It is obvious that the most important struggle against political violence requires socio-cultural practices.

\section{Conclusion}

This study reveals that in terms of multicultural destruction, it is necessary to research inter-ethnic conflicts and forecast possible scenarios for their development. The role of literature in the spread of certain ideas and views (contributing to social stability, or destroying it) is important. Conflicts of contemporary reality, political violence, and its extreme form - terrorism - are the subject of not only political science, sociology, ethnology, and social philosophy, but also of many literary works. A literary text is a source for identifying the key causes of political violence, ethnic, and national conflicts, and it can identify ways to resolve them. Images and symbols created by contemporary literature are useful for further integration into a universal system of values and meanings. These are important to maintain stability in inter-ethnic social relations. Contemporary world writers focus on such themes as islamization of Europe, inter-confessional conflicts, total changes in the inter-ethnic 
relations, fragmentation of common cultural space, and social and cultural transformation leading to conflicts. These are found in the works of Andrei Volos (Russia, Maskavskaya Mecca, 2003), and Elena Chudinova (Russia, The Mosque of Notre Dame, 2005). Some authors ponder over terrorism as an extremist's reaction to social injustice, or an inner personal cultural and religious contradiction, like John Updike (The USA, Terrorist, 2006), and Don DeLillo (The USA, Falling Man, 2007).

As the conflicts of contemporary reality, specifically, political violence and terrorism, are a sociocultural phenomenon, they become the subject of reflection and the study of both, political and literary studies. We believe that in this case, we can talk about new technologies in education, implementing inter-disciplinary approaches in teaching students who are majoring in both Political Studies and Literary Studies in the Transbaikal State University. In the course of Political Studies the students study literary texts of the 2000s (for example, Andrei Volos of Russia, Maskavskaya Mecca, 2003, Elena Chudinova of Russia, The Mosque of Notre Dame, 2005, John Updike, USA, Terrorist, 2006, and Don DeLillo, USA, Falling Man, 2007) for a deeper understanding of contemporary political reality. In the course of modern literature, elements of political studies are included for students, majoring in literary studies, that are necessary for a fuller understanding of the latest literary texts, characterized by an appeal of the problems in ethno-social and political conflicts.

\section{References}

Antonius, D. (2013). The political psychology of terrorism fears. New York: Oxford University Press.

Antonyan, Y. (1998). Terrorizm. Kriminologicheskoye i ugolovno-pravovoye issledovaniye [Terrorism. Criminological and criminal-legal research]. Moscow: Shchit.

Baker, M. (2010). Narratives of terrorism and security: 'accurate' translations, suspicious frames. Critical Studies on Terrorism, 3(3), 347-364. doi: 10.1080/17539153.2010.521639.

Belkov, O. (2002). Mezhdunarodnyy terrorizm: slova i smysly [International terrorism: words and meanings]. Authority, 2, $17-24$

Bjørgo, T. (Ed.). (2004). Root causes of terrorism: Myths, reality and ways forward. Oxon: Routledge.

Bondar-Tereshchenko, I. (2014). Gor'kiy rafinad. V romannoy mirre Vladimira Rafeyenko [Bitter lump sugar. In the romantic myrrh of Vladimir Rafeenko]. New Literary Observer, 1, 125.

Chantsev, A. (2007). Fabrika antiutopiy: Distopicheskiy diskurs v rossiyskoy literature serediny 2000 [Factory of dystopias: dystopian discourse in Russian literature of mid-2000s]. New Literary Observer, 86, 269-301.

Chudinova, E. (2005). Mechet' parizhskoy bogomateri [The Mosque of Notre Dame]. Moscow: Yauza.

Dashkova, S. \& Karchagin, Y. (2013). Ideya spravedlivosti v terrorizme [Idea of justice in terrorism]. Historical, philosophical, political and law sciences, cultural studies and art studies. Theory and practice, (8) 34, 70-74.

DeLillo, D. (2007). Falling man. New York: Simon and Schuster.

Hoffman, B. (2013). Inside Terrorism. New York: Columbia University Press.

Lanin, B. (2008). Voobrazhayemaya Rossiya v sovremennoy russkoy antiutopii [Imaginary Russia in modern Russian antiutopia]. In Mochizuki Tetsuo (Ed.), Beyond the Empire: Images of Russia in the Eurasian Cultural Context (pp. 375-391). Sapporo: Hokkaido University.

Levashov, V. (2005). Bezopasnost' i terrorizm [Security and Terrorism]. Sociological Studies, 7, 75.

Lobin, A. (2014). K voprosu o mekhanizme sotsial'nogo vzryva v romane-antiutopii A. Volosa "Maskavskaya Mekka" [About the mechanism of social explosion in the dystopian novel "Maskavskaya Mecca" by A. Volos]. Contemporary problems of science and education, 3. Retrieved from: http://www.science-education.ru/117-13694.

Malashenko, A. (2006). Kakim nam viditsya islam [How we see Islam]. Russia in global politics, 5, 116-129.

Maltseva, V. (2007). Terrorizm v al'ternativnykh usloviyakh globalizatsii «po-amerikanski» [Terrorism in alternative conditions of "American" globalization]. Authority, 1, 74-78.

Manyukov, S. (2010). Voyna protiv razuma i dushi [The war against the mind and soul]. Foundations of life security, 3, 3543. 
Moghaddam, F.M. (2006). From the terrorists' point of view: What they experience and why they come to destroy. London: Greenwood Publishing Group.

Romanova, A. (2013). Kul'turnaya bezopasnost' i strakh pered Chuzhim [Cultural security and fear of the stranger]. Caspian region: politics, economics, culture, 2, 228-237.

Updike, J. (2007). Terrorist. UK: Penguin.

Volos, A. (2003). Maskavskaya Mekka [Maskavskaya Mecca]. Moscow: EKSMO.

Voronchenko, T., Vinogradova, N., \& Zherebtsova, E. (2014). Teacher's professional health as a factor of the development of a student's harmonic personality (on J. Updike's novel “Terrorist”). Procedia - Social and Behavioral Sciences, 159, 235238. doi: 10.1016/j.sbspro.2014.12.364.

Voronchenko, T. \& Zherebtsova, E. (2013). London publication of the novel "The Career of a Nihilist" by S. StepnyakKravchinsky (1889): the problem of Russian terrorism. Nauka i studia, 16 (84), 49-54.

Žindžiuvienè, I. (2013). Elements of trauma fiction in the 9/11 novel. BAS British and American Studies, 19, 71-81. 